Анжела Прохорова

Универзитет у Новом Саду

Филозофски факултет

Одсек за славистику

anzela.prohorova@ff.uns.ac.rs
УДК 811.163 .41 '38

https://doi.org/10.18485/slavistika.2021.25.2.9

Оригиналан научни рад примљено 4.6.2021.

прихваћено за штампу 6.10.2021.

\title{
МЕТАФОРЕ ПАНДЕМИЈЕ КОВИД-19 У ЈАВНОМ ДИСКУРСУ СРБИЈЕ
}

Од марта до децембра 2020. године у јавном дискурсу Србије појавиле су се бројне метафоре којима се описује понашање новог вируса. Неке од их метафора су уобичајене при опису болести, временских непогода и других врста катастрофа, а неке од њих су потпуно нове. У својој анализи ослањали смо се на основне постулате когнитивне лингвистике, према којима метафоре нису само експресивно језичко средство, већ активно учествују у креирању значења и тиме врше важан утицај на процесе људског мишљења. Покушали смо да сагледамо шири контекст настанка ових метафора у новонасталој изванјезичкој ситуацији, да их класификујемо према сферама из којих се „позајмљују” особине и пресликавају у другу сферу реалности, да објаснимо мотивацију таквог позајмљивања и експлицирамо евентуално скривене поруке које ове метафоре носе.

Кључне речи: метафора, концептуализација, пандемија, вирус, језичка слика света.

From March to December 2020, numerous metaphors appeared in the public discourse of Serbia describing the behavior of the new virus. Some of these metaphors are common in describing diseases, weather disasters, and other types of disasters, and some of them are completely new. In our analysis, we relied on the basic postulates of cognitive linguistics, according to which metaphors are not only an expressive linguistic tool, but actively participate in the creation of meaning and thus exert an important influence on the processes of human thought. We tried to look at the broader context of the origin of these metaphors in the new situation, to classify them according to the spheres from which features are «borrowed» and mapped to another sphere of reality, to explain the motivation for such borrowing and to explain the hidden messages of these metaphors.

Keywords: metaphor, conceptualization, pandemic, virus, linguistic picture of the world.

Од самог почетка пандемије сведоци смо како се вирус, који се у медијима често назива „невидљиви непријатељ”, трансформисао из уобичајено присутног око нас инфективног агенса у лукавог и активног субјекта чијој се вољи покоравају државе и континенти, и како смо се преко ноћи обрели у неком сасвим новом свету у којем важе „нова нормална” правила. За описивање понашања овог вируса често се прибегава метафори као веома изражајном језичком средству. Употреба метафоре у датом контексту има за циљ да на експресиван начин конципира вирус и његово понашање, али и да истакне поједине аспекте изванјезичке стварности, који би употребом других, мање експресивних, језичких средстава били мање уочљиви.

У овом раду истражићемо концептуалну метафору која се односи на различите аспекте актуелне епидемије. Руководимо се основном претпоставком Џ. Лејкофа (George Lakoff) да је метафоризација заснована на узајамном деловању две когнитивне структуре - домена „извора” и „циљног” домена (source domain и target domain). У процесу метафоризације структура циљног домена се структурише према обрасцу извора, тј. долази до метафоричке пројекције 
(metaphorical mapping), при чему се у циљном домену могу активирати нове особине предмета које до сада нису биле актуелне (Лакофф 2004: 9-10).

Употреба метафоре у условима кризе изазване епидемијом има своју важну когнитивну функцију, а то је, с једне стране, пренос информација и представљање нових сазнања путем сажетих и експресивних конструкција, а, са друге стране, с обзиром на то да је метафора веома експресивно језичко средство, она утиче на нашу свест и подсвест, на понашање и однос према другим људима. Како сам Лејкоф каже, концепти који управљају нашим мишљењем нису само продукти нашег ума, већ утичу на нашу свакодневну активност све до најситнијих детаља (Лакофф 2004: 25).

Метафоре пандемије показују како су у метафоричком огледалу одражене представе о овој болести у јавном дискурсу Србије. Креатори ових представа су различити: почев од политичара и високих функционера, који их користе у својим јавним саопштењима, преко представника медицинске струке, па до новинара и обичних људи који остављају коментаре на друштвеним мрежама.

Циљ овог истраживања је да уђемо у срж метафоричких процеса тако што ћемо одредити метафоричке моделе, као и најзаступљеније типове метафоре у оквиру датих модела. Одређивање метафоричких модела нам пружа информације о томе који се циљни домени најчешће пројектују на изворне домене, а одређивање типова метафора нам даје информације о особинама саме метафоре.

Корпус истраживања чине насумично одабрани новински текстови у периоду од марта до децембра 2020. године, као и јавна саопштења која се могу наћи на сајту Министарства здравља.

Примећено је да је у друштву у кризним периодима повећана фреквентност употребе метафоре. Тако метафора може да послужи као средство за сагледавање и представљање проблемске сутуације, али и као средство за решавање проблема и доношење одлука (Баранов 2014: 19).

Употреба метафоре у опису медицинских концепата није нова појава. Веома често метафора је једино средство помоћу којег може да се опише нека сложена и ускостручна проблематика, а понекад метафора спречава неоправдано проширивање научног језика, јер на лапидаран начин изражава научну мисао (Зубкова 2008: 127-128).

Све врсте метафоре одредили смо у складу са Лејкофовим и Џонсоновим системом класификације у којем се издвајају структурне, оријентационе и онтолошке метафоре (Лакофф 2004).

\section{Метафора рата}

Метафора рата представља врсту метафоре која у својој семантичкој структури има имплицитно или експлицитно присутну сему „рат”. Медицина и рат су две сфере којима је заједнички компонент борба: у првом случају се води борба за живот пацијента или за оздрављење, а у другом случају то су ратне операције које имају за циљ освајање територије или одређене сфере утицаја. У метафоричком моделу БолЕСт ЈЕ РАТ победа или пораз у борби за здравље се доживљавају као ратне операције (Федотова 2018: 61). 
Метафора рата није новина у медицинском контексту. Као што смо већ напоменули, она је дубоко утемељена у нашем искуству, када је у питању болест. У принципу, свака болест може да се концептуализује као мали рат између непријатељске војске која напада (вируси, бактерије) и војске која се брани (наша антитела) (Štrkalj Despot 2020: 6).

Иако процес ширења и напада вируса на ћелије јесте реалан и, ако би се посматрао микроскопом, јасно бисмо га могли видети, ипак, за већину људи који немају приступ лабораторији нити су икада видели вирус или ћелију, овај процес је апстрактан и управо тиме може бити мотивисана употреба метафоре рата. На тај начин се невидљиви процес приближава нашој перцепцији тако што се искуство рата, тачније онај део рата који подразумева напад, борбу, одбрану и сл. пројектује у област болести. Когнитивна слика рата „приземљује” апстрактни концепт (у датом случају то је процес ширења микрочестице у телу домаћина) у материјалну сферу која је ближа нашем искуству. Сви знају шта је рат, али већина не зна који се то процеси дешавају у организму за време болести, па метафора олакшава то разумевање.

У оквиру датог модела прикупили смо 60 примера. Све примере смо посматрали на основу врсте ратне терминологије која се користи, па смо издвојили метафоре које се односе на ратне операције, локацију ратних дејстава, врсту оружја, начин вођења рата, учеснике у рату, ратне формације, укључивағе у рат и ратно распоређивање.

Највећи број примера је из групе ратна операција. У овој групи налазимо лексеме рат, борба (борити се), победа (победити), повлачење, инвазија, напад, окупација (окупирати), експлозија, битка, удар, предаја. „Инвазија короне” (10.11.20. https://www.kurir.rs). „Корона напала НАТО на Косову” (18.12.2020. https://www.kurir.rs/vesti/drustvo/).

Следећа по бројности је група локација ратних операција. У овој групи налазимо следеће метафоре: фронт борбе, прва линија одбране и линија фронma. Примери: „Хигијена руку је прва линија одбране од новог корона вируса” (19.03.2020. https://pro100healthy.rs); „Важно је схватити да је свако од нас на линији фронта у борби против коронавируса" (15.04.2020. https://www.srbija. gov.rs) .

Следећа група примера се односи на оружје. У овој групи наилазимо на метафоричку употребу лексема оружје, арсенал оружја и бомба. На пример: „Свети Никола је потенцијална корона бомба”(18.12.2020. https://www.blic.rs); „Поред арсенала оружја против коронавируса - маски, самоизолације и социјалног дистанцирања, једно је било посебно лако занемарити: прање руку.” (5.10.20. www.bbc.com).

У групи начин вођења рата наилазимо на метафоричку употребу лексема стратегија и тактика. Пример: „Да ли је шведска тактика против короне успела" (28.07.2020. https://www.bbc.com).

У групи учесници у рату наилазимо на метафоричку употребу лексема непријатељь и нападач. Пример: „А вирус је ту, испред нас, поред нас и иза нас. Ми га не видимо. То је наш невидљиви непријатељ и невидљиви нападач”. (30.06.2020. https://n1 info.com/) . 
У групи ратна формација нашла се лексема хорда. Пример: „Хорда новог бацила из породице коронавируса..." (11.04.2020. https://naukakrozprice.rs/ kako-virus-ubija/). Метафора је интересантна, јер се хорда као војни термин не употребљава често и у буквалном значењу се односи на административно-војни облик организовања татарских и монголских племена. Ова племена су била ратоборна и одликовала су се посебном крволочношћу, па се ова лексема много чешће употребљава у пренесеном значењу да означи освајаче, пљачкаше или неке друге агресивне и необуздане групе људи.

У групи укључивање у рат и ратно распоређивање наилазимо на метафоричку употребу лексема мобилизација и ратни распоред. На пример: „Циљ ове донације је дугорочна подршка и нека врста иницијативе за мобилизацију свих друштвено-одговорних фирми и појединаца да се сви заједно укључе у борбу против корона вируса.” (20.03.2020. https://givingbalkans.org).

\section{Математичка метафора}

У току пандемије здравствени службеници и државни званичници су нас редовно обавештавали о тренутном броју заражених и при томе су веома често користили различите математичке моделе, термине и устаљене конструкције које су из других области доспеле у математику. Математичком метафором називамо све оне примере у којима се употребљава одређени математички модел или се на неки други начин оперише математичким појмовима. Ексцерпирали смо 47 примера овог типа.

Највише математичких метафора заступљено је математичким моделом зоне. Уже гледано ово су заправо метафоре боје и помоћу њих су представљене зоне распрострањености вируса на одређеној територији. Има најмање два оваква модела. Првом припадају зелена, жута, наранџаста, црвена и љубичаста боја, а у другом моделу су бела, сива и црна боја. Пример: „Evropski centar za prevenciju i kontrolu bolesti (ECDC) zemlje deli po zonama koje su označene bojama: zelena zona (od 0 do 15 zaraženih na 100.000), žuta zona (15-30 zaraženih na 100.000), crvena zona (30-50 zaraženih na 100.000), kao i ljubičasta zona (50+ zaraženih na 100.000 stanovnika)." (29.10.2020. https://rs-lat.sputniknews.com). Поред набројаних боја појављују се и њихове нијансе и то, пре свега, нијанса љубичасте (тамнољубичаста зона) и нијанса сиве (тамносива зона).

Следећа по броју примера је група метафора која указује на број заражених. Овај број може да „расте”, „пада”, „драматично скаче”, да буде „у порасту” (при чему се често изоставља лексема „број” и каже се „вирус је у порасту”, али овај број може и да „опада (пада)” и „смањује се”, „успорава”. На пример: „Забележен је драматичан скок броја оболелих”. Дакле ове математичке метафоре указују на кретање одоздо нагоре, одозго надоле, на брзину кретања (успоравање) и на промену физичког облика („смањује се”). На пример: „Вирус је и даље у порасту, успоравање средином децембра" (27.11.20. https://balkans. aljazeera.net/news/). Многе од ових конструкција су устаљене и одомаћиле су се у математичкој сфери (на пример, пораст/опадање броја).

Посебну групу метафора чине устаљени математички термини који се односе на број заражених и на математичке вредности које описују ширење 
вируса. То су речи и изрази који се као већ формиране метафоре редовно употребљавају у математичком контексту. На пример: геометријска прогресија, експонениијална крива, стопа обољевања, вирус је на максимуму, функичја раста, линеарни раст, експоненцијални раст итд. Пример: „Вирус се увек шири геометријском прогресијом" (08.08.2020. http://www.politika.rs).

Још један математички модел помоћу којег се приказује број заражених и врше предвиђања о будућем кретању овог броја је модел криве. Ова крива може да расте, пада, може се спљоштити, заравнити, чак се употребаљава и жаргонизам пеглати криву. Неретко смо у медијима могли чути израз да нам је циљ да „спљоштимо криву”. Пример: Šta znači „,spljoštiti krivu” širenja i zašto je to ključno ... (27.03.2020. https://www.bbc.com).

У овој групи су и метафоре које се односе на вредност броја заражених, али је овај број представљен таласом. Талас представља шематски приказ исте те криве (позната крива британског епидемиолога Нила Фергусона) која има своје „успоне” или „Пикове” (највише тачке) и „падове”. На пример: „Пик таласа нас очекује до краја недеље" (10.11.2020. https://www.kurir.rs/).

\section{Медицинска метафора}

У медицинску метафору смо уврстили речи и конструкције које се иначе користе као медицински термини, али због актуелне епидемиолошке ситуације је повећана њихова фреквентност у језику. То су конструкције типа бити позитиван (на вирус), нулти пацијент, локална трансмисија, имунитет крда (или колективни имунитет), ланаи преношења и др. До појаве актуелне епидемије шира јавност није ни била упозната са значењем неких од ових термина, а сада су се они нашли у нашем свакодневном језику.

Са друге стране неки медицински термини, који се у области медицине користе у буквалном значењу, у језику медија постају метафоре. На пример, термин колапс, који се у медицини дефинише као „изненадан и најчешће ненајављен губитак постуларног тонуса, осећај слабости или хипотонија, који је често, али не нужно праћен губитком свести", ${ }^{1}$ употребљава се у пренесеном значењу у потпуно другом контексту. Пример: „Здравствени систем је на ивици колапca." (23.11.2020. https://insajder.net/). Ова метафора се често користи и у другим контекстима (на пример, колапс у саобраћаjy), али је њено порекло свакако медицинско. Такође се као метафора у немедицинском контексту употребљава и медицински термин епидемија. На пример: „Уз корона вирус и епидемија лажних вести" (28.02.2020. https://www.danas.rs/).

\section{Спортска метафора}

Забележили смо10 метафора овог типа. Спортска метафора се на неки начин преплиће са ратном метафором, јер, као и у рату, у спорту такође постоје две стране које се међусобно боре. У спорту је та борба заправо игра и у основи јој је такмичење, док је у рату то борба на живот и смрт. У ову врсту ме-

\footnotetext{
${ }^{1}$ Slijepčević D., Vujović S. Medicinska enciklopedija, T2. Beogradska knjiga, 2011.
} 
тафоре су укључене две групе примера, који се односе на две спортске дисциплине. У првој групи се борба са вирусом претвара у „трку са вирусом”, „трку са временом” и „трку за вакцином”. У неким ситуацијама та трка прераста у маратон или у спринт. На пример: „Маратон, а не спринт је реченица Андреса Тегнелла, шведског епидемиолога, која можда и најбоље описује како изгледа борба са короном.” (18.12.20. javniservis.me). У другој групи примера се глобална борба са вирусом поистовећује са фудбалском утакмицом, која има прво и друго полувреме. У оваквим примерима у основи спортске метафоре је заправо временска одредница. На пример: „Епидемиолог Предраг Кон изјавио је јутрос да је Србија завршила 'прво полувреме’ у борби против корона вируса." (11.04.20. www.danas.rs). У датој метафори од свих особина које фудбал као спортска дисциплина подразумева, узете су само особине које указују на време.

\section{Метафора катастрофе}

У овој групи су метафоре које се односе на неки вид природне катастрофе: поплаве, земљотреса, цунамија и слично. Регистровали смо 9 примера у овој групи. Најбројнији примери су они са компонентом талас. Варијација ове метафоре је иунами. Овај тип метафоре треба разликовати од математичке метафоре која такође има компоненту талас, јер се под тим таласом подразумева крива са одређеним вредностима у јединици времена. Код метафоре катастрофе у основи је поређење са воденим таласом који изазива катастрофу. На пример: „Талас наилази, неће нас заобићи” (3.04.20. https:/www.novosti. rs/). Или: „Станић објашњава како избећи цунами корона вируса.” (04.07.2020. https://srpskainfo.com). Следећи по бројности су примери са компонентом жариште. Жариште је метафора која се иначе често употребљава у контексту болести и рата и указује на подручје, где су заразна болест или ратно дејство најприсутнији. На пример: „Највеће жариште је и даље Крушевац, регистровано 87 нових случајева заразе." (29.11.20. https://www.novosti.rs/). Поред лексеме жариште, као метафора катастрофе употребљава се и друга, семантички веома блиска лексема, а то је епицентар. Иако се у буквалном значењу ова лексема употребљава у контексту земљотреса, она се нашла и у примерима који описују пандемију и тамо је семантички изједначена са лексемом жариште. На пример: „Индија постаје светски епищентар заразе короном.” (2.09.20. https://beta. rs/vesti).

У овој групи метафора су и примери који експлицитно садрже лексему каmacmpoфа. На пример: „Др Кон изнео застрашујуће податке: Близу смо корона катастрофе!" (10.11.20. https:/www.kurir.rs/). Оваквих примера је најмање у овој групи.

\section{Метафоре контроле}

Пронашли смо 9 примера у овој групи. У највећем броју примера вирус је главни актер који „преузима контролу (комплетну нашу стварност)”, ,,зауставља свет”, „зауставља Евролигу и Еврокуп”, „приземљује авионе”, ,зауставља жичаре у Вал Гардени" итд. Вирус је тај који контролише авионски саобраћај, 
спортске догађаје, туристичка путовања и слично, па се доживљава као неко апстрактно моћно биће које има утицаја на скоро све аспекте нашег живота. На пример: „Korona virus zaustavio žičare u Val Gardeni.” (23.03.2021. https:/www. telegraf.rs).

У ову групу сврстали смо и зоометафору „у канџама короне”, мада се она може посматрати и као метафора деструкције. У овој метафори вирус се изједначава са некаквом крволочном грабљивицом у чијим је канџама читав свет. На пример, један од наслова Курира од 10.11.2020. гласи: „Србија у канцама короне”. Овај пример је интересантан и по томе што представља једину зоометафору у овој групи.

\section{Метафоре кретања}

Пронађено је укупно 7 примера у овој групи. Свима је заједничко то што имају неки глагол кретања у свом саставу (вирус побегао, вирус успорава (убрзава), вирус се приближава, вирус ушао, вирус је пуштен). Вирус се, слично као и код метафоре контроле, доживљава као неко моћно биће које има слободу кретања и утицај на све важне аспекте нашег живота. На пример: „Корона је ушла у Геронтолошки центар у Нишу.” (22.11.2020. www.juznevesti.com).

\section{Метафоре деструкције}

Има 5 примера у овој групи. Главни актер ових метафора је вирус који је ,заточио људе”, „срушио светску економију”, „оставио пустош за собом” и „усмртио велики број људи”. Ове метафоре нас поново наводе да доживимо вирус као биће које има велики утицај на наше животе и велику разорну моћ. На пример: „Radovanović kaže za Telegraf.rs da mu je bilo jasno kakav potencijal ima korona virus čim je video kakvu je pustoš ostavio na Dalekom istoku." (15.04.2020. www.telegraf.rs).

Посебно је интересантан пример са глаголом разгоропадити. На пример: „А можда се вирус баш ту, усред Балкана разгоропадио.” (09.10.2020. http:// srbinaokup.info). Вирусу се осим разорне моћи, на коју се овде експлицитно указује, приписује и емоционално стање. Глагол разгоропадити означава побеснети, наљутити се, а синоним му је глагол помамити који указује на веома висок степен љутње.

\section{Закључак}

Истраживање метафора пандемије ковид-19 у јавном дискурсу Србије је показало да су у периоду од марта до децембра 2020. године биле присутне следеће метафоре: метафора рата, математичка метафора, медицинска метафора, спортска метафора, метафора катастрофе, метафора контроле, метафора кретања и метафора деструкције.

Истраживање метафоре рата је показало да је у јавном дискурсу у поменутом периоду употребљаван веома широк опсег ратне терминологије. Дате метафоре се односе на ратне операције, локацију ратних дејстава, врсту оружја, начин вођења рата, учеснике у рату, ратне формације, укључивање у рат и ратно распоређивање. 
Најзаступљенији тип ратне метафоре је структурна метафора. Присутна је и онтолошка метафора. Као оријентациону метафору смо посматрали конструкцију експлозија броја новозаражених због специфичне оријентације нагоре која је у основи ове метафоре.

У оквиру математичке метафоре издвајају се, с једне стране, два математичка модела: модел зоне представљен различитим бојама које указују на број оболелих на одређеној територији и модел криве који такође приказује број заражених. Са друге стране, у овој групи су и метафоре које су устаљене у области математике као што су: геометријска прогресија, експоненцијална крива итд. У метафорама боје у оквиру овог модела употребљава се традиционална симболика боја на коју наилазимо и у другим математичким моделима (на пример, љубичастом бојом се поред зоне са највећим бројем оболелих на 100000 становника означава и степен највеће загађености ваздуха на одређеној територији). Симболика боја је таква да тамнија нијанса указује на већу бројчану вредност, а светлија на мању. Примењује се и општеприхваћена симболика: на пример, црвена боја значи већу опасност, а зелена боја мању или одсуство опасности.

У оквиру математичке метафоре забележено је највеће присуство оријентационе метафоре. Најчешћи тип оријентације је одоздо нагоре и с лева на десно. Равноправно је присутна и структурна метафора, а онтолошка метафора је најмање заступљена (свега један пример).

У групи медицинске метафоре такође се издваја неколико подгрупа. Највећи број метафора су медицински термини који се иначе користе у медицини, али је у току епидемије повећана фреквентност њихове употребе (нулти пащијент, локална трансмисија, бити позитиван, имунитет крда). У другој групи су медицински термини који се употребљавају у пренесеном значењу у немедицинском контексту (колапс у болницама, епидемија лажних вести).

Највећи број медицинских метафора су структурне метафоре. Метафора ланац преношења може се посматрати као оријентациона метафора, јер подразумева линеарну оријентацију у простору. У овој групи нисмо забележили онтолошке метафоре.

Спортска метафора се на неки начин преплиће са метафором рата, јер је у основи обе метафоре присутна борба две стране. У спорту то није борба на живот и смрт као у рату, већ је игра. У оквиру спортске метафоре налазимо спортске термине који представљају називе спортских дисциплина (трка, маратон, спринт) или термине у оквиру појединих спортских дисциплина (прво полувреме, друго полувреме). Интересантно је да се у свим примерима ради о спортским дисциплинама које подразумевају трчање, а удубљивањем у ове метафоре долазимо до закључка да су све оне на неки начин повезане са временом. На пример, ако се борба са вирусом упоређује са маратоном, то нам говори о дужини трајања те борбе, или, ако се упоређује са првим или другим полувременом утакмице, то нам говори о етапи те борбе. У свакој од ових метафора активирају се и друге компоненте извора: на пример, при упоређивању са маратоном, активира се упоредо и компонента издржљивост која је неопходна за овај спорт. Све спортске метафоре припадају структурном типу. 
У групи метафора катастрофе су примери који се односе на неки вид природне катастрофе, најчешће поплаве и земљотреса. Најбројнији су примери са компонентом талас и жариште. Постоје варијанте ових метафора у чијој су основи синоними, на пример, варијанта за метафору талас коронавируса је иунами коронавируса, а варијанта за метафору жариште је епицентар. Најмање су заступљени примери са компонентом катастрофа. Све метафоре ове групе припадају структурној метафори.

Метафорама контроле, кретања и деструкције заједничко је то да третирају вирус као некакво моћно биће које утиче на скоро све аспекте људског живота. То биће је агресивно, попут дивље звери или птице грабљивице, оно нас ограничава у многим активностима, а само има неограничену слободу кретања. Оно има и емоционалне карактеристике и у стању је да се „разгоропади”. Све метафоре ове групе припадају онтолошком типу.

\section{Цитирана литература}

Баранов А.Н. Дескрипторная теория метафоры. Москва: Языки славянской культуры, 2014.

[Baranov A.N. Deskriptornaiâ teoriiā metafory. M.: Iâzyki slaviânskoĭ kul'tury, 2014.].

Зубкова О. С. «Медицинская метафора как результат культурной фиксации в медицинской терминологии.» Вестник Ленинградского государственного университета им. А.С. Пушкина, 2008: 127-135.<https://socionet.ru/d/spz:cyberleninka:252:14781908/ http://cyberleninka.ru/article/n/meditsinskaya-metafora-kak-rezultat-kulturnoy-fiksatsii-vmeditsinskoy-terminologii>

[Zubkova O. S. "Meditsinskaiā metafora kak rezul'tat kul'turnoî fiksatșii v meditsinskoŭ terminologii.» Vestnik Leningradskogo gosudarstvennogo universiteta im. A.S. Pushkina, 2008. c. 127-135. <https://socionet.ru/d/spz:cyberleninka:252:14781908/ http://cyberleninka.ru/article/n/meditsinskaya-metafora-kak-rezultat-kulturnoy-fiksatsiiv-meditsinskoy-terminologii $>$ ]

Лакофф Дж., Джонсон М. Метафоры, которыми мы живем. Пер. с англ./ Под ред. и с предисл. А.Н. Баранова. Москва: Едиториал УРСС, 2004.

[Lakoff Dzh., Dzhonson M. Metafory, kotorymi my zhivem. Per. s angl./ Pod red. I s predisl. A.N. Baranova. M.: Editorial URSS, 2004.]

Федотова В. «Специфика употребления военной метафоры в медицинском дискурсе.» Вестник ВГУ. Серия: Филология. Воронежский государственный университет, 2018: 60-62. <http://www.vestnik.vsu.ru/pdf/phylolog/2018/02/2018-02-15.pdf> 23 апреля 2018 г.

[Fedotova V. «Spetsifika upotrebleniiâ voennoĭ metafory v meditsinskom diskurse.» Vestnik VGU. Seriiā: Filologiiâ. Voronezhskiı̆ gosudarstvennyĭ universitet. $<$ http://www. vestnik.vsu.ru/pdf/phylolog/2018/02/2018-02-15.pdf $>23$ apreliā 2018 g. s. 60-62.]

Štrkalj Despot, K. „Kako koronavirus mijenja jezik kojim govorimo (i mislimo)?” Hrvatski jezik. Znanstveno-popularni časopis za kulturu hrvatskoga jezika 7/2. 2020: 1-7. 


\title{
Анжела Прохорова
}

\section{МЕТАФОРЫ КОВИД-19 В ПУБЛИЧНОМ ДИСКУРСЕ СЕРБИИ}

\begin{abstract}
Резюме
Статья посвящена анализу метафор, появившихся в сербских СМИ с марта 2020 года, когда была официально объявлена пандемия коронавируса. С самого начала информирования общественности о коронавирусе мы были свидетелями того, как этот «невидимый враг» превратился из инфекционного агенса, обычно присутствующего вокруг нас, в хитрого и активного субъекта, чьей воле подчиняются государства и континенты, и как возник совершенно иной мир „новой нормальности”, подавливая на неопределенное время привычную жизнь. Некоторые из метафор, используемых для описания вируса, регулярно употребляются в аналогичных ситуациях при описании болезней, природных катаклизмов и различных стихийных бедствий, а некоторые из них являются совершенно новыми. В своем анализе мы опирались на основные постулаты когнитивной лингвистики, согласно которым метафоры являются не только выразительным лингвистическим инструментом, но и активно участвуют в создании значения и тем самым оказывают важное влияние на процессы человеческого мышления. Мы попытались взглянуть на более широкий контекст порождения этих метафор в новой внеязыковой ситуации, классифицировать их по сферам, из которых заимствованы элементы и сопоставлены с другой сферой реальности, объяснить мотивацию такого заимствования и имплицитно указать на скрытые сообщения, которые несут эти метафоры.
\end{abstract}

Ключевые слова: метафора, концептуализация, пандемия, вирус, языковая картина мира. 